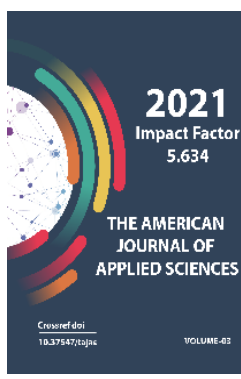

Journal Website: http://theamericanjour nals.com/index.php/taj as

Copyright: Original content from this work may be used under the terms of the creative commons attributes 4.0 licence.

\section{Ways To Develop The Language Competence For Future Teachers}

\author{
Rahmonova Dildora Abdulhamid Qizi \\ Teacher, Faculty Of World Languages, Namangan State University, Namangan, Uzbekistan \\ Yuldasheva Ma'mura Boqijonovna \\ Teacher, Faculty Of World Languages, Namangan State University, Namangan, Uzbekistan \\ Karimova Sadoqat Abdulhamidovna \\ Teacher, Faculty Of World Languages, Namangan State University, Namangan, Uzbekistan \\ Nuriddinova Nodira Adhamovna \\ English Teacher At School №1 Namangan, Uzbekistan
}

\title{
ABSTRACT
}

This article discusses effective methods of developing language competence in future teachers and lists a number of useful methods.

\section{KEYWORDS}

Language competence, innovative method, active and passive methods, interactive methods, the formation of language competence.

\section{INTRODUCTION}

The problem of improving the language knowledge for future teachers has always been one of the most urgent in the process of teaching foreign languages in universities. Therefore, one of the important priorities of researchers is the constant search for teaching methods that allow teachers and students to effectively use joint cognitive activities. There are some effective teaching methods that should be available today:

- Use methods based on interactive forms of learning;
- Be proactive in learning the language, be sincere in relationships with others;

- Analysis of educational activities;

- Implementation of creative research potential;

- Preparation for a future professional career;

- Defend your position, perceive criticism correctly and work on your mistakes.

The learning process consists of two stages. The first is to share knowledge. The second is the acquisition of knowledge. This means that 
the teacher provides information and the students accept it. This process is enriched with innovative methods. The goal is to create new teaching methods and techniques. It is also important to measure the performance of teachers and students using the new technical guidelines.

\section{MAIN PART}

The methodological approach of teaching a foreign language is divided into three groups. These are passive methods, active methods, interactive methods.

Passive methods are organized in the educational process only with the active participation of the teacher. In this case, the teacher is at the centre of the learning process. Students participate as passive listeners. In this process, the teacher can use quiz questions, tests or individual question and answer methods.

In the second method students and teachers are active in the spotlight. Their roles and actions in the educational process are evenly distributed. Students will be able to ask questions and even share their thoughts with the teacher.

An interactive method is a modernized form of the active method. Most teachers are used to interacting with students throughout the lesson. However, the teacher must have an intrinsic motivation that encourages students to be active. The role of the teacher is to engage students in the lesson through interactive activities and assignments. One of the ways that a foreign language is associated with major methodological innovations is through interactive methods.
Interactive methods are the most effective way of teaching foreign languages and increasing knowledge, skills and experience. Special materials should be used to develop professional communication skills in a foreign language. It is also important to follow the rules of professional language communication ethics. In my opinion, in the modern educational process, special attention should be paid to the following methods:

- The classroom should create an environment in which students feel at ease;

- Correctly selected information materials must be provided for the benefit of the students;

- Students should be more active and encouraged to exchange ideas;

- Need to take into account the interests of students;

- It is necessary to develop the speech, cognitive and creative abilities of students, fully drawing their attention to the learning process, based on their abilities;

- Encourage students to actively interact with each other and with the teacher, making them the protagonists of the learning process;

- Individualize the learning process;

Below are some interactive ways for learners to build language competencies.

Brainstorm. This method helps to form new ideas on a topic in language acquisition. This method teaches students to solve problems, increase their creativity and express their thoughts freely. In a mental attack, word count is important and quality is not taken into account. The teacher should listen to everything without criticizing. Instead, invite 
students to suggest as many options as possible. The lack of criticism allows students to express their thoughts freely. At the end of the brainstorming session, all statements are recorded and then analysed.

This type of interactive method requires studying the subject matter before starting a discussion. Students can start a conversation by studying lexical and grammatical materials on the topic. This method helps students to express their ideas consistently and logically and also gives students a foundation to correct their speech. At the same time, students work in small groups, which increase their activity. Each member of the group can express their opinion and take part in the discussion. The forms of organization of group work are as follows:

a) On the chosen topic;

b) How the subject is studied;

c) Groups are formed;

d) The teacher gives instructions and announces the time;

e) The teacher guides the activities of students and, if necessary, helps and encourages them;

f) At the end of the discussion, one representative from each group will give their opinion.

The next innovative method is a combination of different types of multimedia in the form of text, audio and video materials, with the help of which the teacher informs the students.

Benefits of using multimedia tools:

- It has a positive effect on fluency and communication skills.
- Multimedia lessons look at the important elements of the lesson and relate them to the purpose of the lesson.

- Improves knowledge and skills such as speaking and listening. Effectively expands students' knowledge, language skills and memorization of acquired knowledge.

\section{CONCLUSION}

The use of interactive tools in modern education helps to achieve effective results. They help in the learning process to use the cognitive knowledge of all students. Each of them contributes to the learning process and students exchange information and ideas. These relationships allow students not only to acquire knowledge but also to develop communication skills.

Develops skills such as listening to others, evaluating different points of view, participating in discussions, making joint decisions, and developing tolerance. Interactive learning allows not only students and teachers but also to learn new materials and memorize them for a long time.

\section{REFERENCES}

1. Chomsky, N. (2014). Aspects of the Theory of Syntax (Vol. 11). MIT press.

2. Chomsky, N. (2006). Language and mind. Cambridge University Press.

3. Christina Bratt Paulston. (1974). Communicative competence. Erfurt: University of Erfurt., 4th ed. pp.353354.

4. Gardner, R. C. (2010). Motivation and second language acquisition: The socio-educational model (Vol. 10). Peter Lang. 
5. Hymes, D., Competence, O. C., \& Hymes, D. (1972). Sociolinhuistics/JB Pride; J Holmes.

6. Røkenes, F. M. (2016). Preparing future teachers to teach with ICT: An investigation of digital competence development in ESL student teachers in a Norwegian teacher education program.

7. Yakubova Dilnoza Mirsharifovna (2018). The problem of increasing professional competence of future teachers. Questions of science and education, (8 (20)), 126-128.

8. Selvi, K. (2010). Teachers' competencies. Cultura International Journal of Philosophy of Culture and Axiology, 7(1), 167-175. 